\title{
Housing problems for middle and low income people in Bangladesh: challenges of Dhaka megacity
}

\begin{abstract}
In Bangladesh, 30 per cent of its total population is living in urban areas and by 2030 the rate of urbanization will be more than 40 per cent. There is a tremendous pressure of influx of people in Dhaka city. Current trend of urban migration is driven by rural poverty, river erosion and natural calamities forcing them to migrate to Dhaka city in search of better livelihoods. These newcomers floating people in the city end up sleeping in public places such as street corners, railway and bus stations as well as other available places including abandoned buildings. The existing infrastructure facilities developed in Dhaka megacity cannot cope with the minimum living requirements of this poor working class floating population. The Dhaka city is exposed to an array of urban problems that could not be discussed in one paper. This article explores the nature and pattern of housing developed under public sector and the policies and strategies that the Government of Bangladesh is pursuing particularly for the middle and poor class who are living permanently in Dhaka city in temporary shelters or on floating basis.
\end{abstract}

Keyword: Housing; Policy; Slums; Urban migration; Urbanization 